\title{
Archaeal lipid-inferred paleohydrology and paleotemperature of Lake Chenghai during the Pleistocene-Holocene transition
}

\author{
Weiwei Sun $^{1}$, Enlou Zhang ${ }^{1,2}$, Jie Chang ${ }^{1}$, James Shulmeister ${ }^{3,4}$, Michael I. Bird ${ }^{5,6}$, Cheng Zhao ${ }^{1,2}$, Qingfeng Jiang ${ }^{7}$, \\ and Ji Shen ${ }^{1}$ \\ ${ }^{1}$ State Key Laboratory of Lake Science and Environment, Nanjing Institute of Geography and Limnology, \\ Chinese Academy of Sciences, Nanjing 210008, China \\ ${ }^{2}$ Center for Excellence in Quaternary Science and Global Change, Chinese Academy of Science, Xian 710061, China \\ ${ }^{3}$ School of Earth and Environmental Sciences, The University of Queensland, St Lucia, Brisbane, Queensland, 4072, Australia \\ ${ }^{4}$ School of Earth and Environment, University of Canterbury, Private Bag 4800, Christchurch, New Zealand \\ ${ }^{5}$ ARC Centre of Excellence for Australian Biodiversity and Heritage, James Cook University, \\ P.O. Box 6811, Cairns, Queensland, 4870, Australia \\ ${ }^{6}$ College of Science and Engineering, James Cook University, P.O. Box 6811, Cairns, Queensland, 4870, Australia \\ ${ }^{7}$ School of Geography Sciences, Nantong University, Nantong, 226007, China
}

Correspondence: Enlou Zhang (elzhang@niglas.ac.cn)

Received: 5 July 2019 - Discussion started: 27 August 2019

Revised: 30 March 2020 - Accepted: 6 April 2020 - Published: 7 May 2020

\begin{abstract}
Over the past decades, paleoenvironmental studies in the Indian summer monsoon region have mainly focused on precipitation change, with few published terrestrial temperature records from the region. We analysed the distribution of isoprenoid glycerol dialkyl glycerol tetraethers (isoGDGTs) in the sediments of Lake Chenghai in southwest China across the Pleistocene-Holocene transition, to extract both regional hydrological and temperature signals for this important transition period. The lake level was reconstructed from the relative abundance of crenarchaeol in isoGDGTs (\%cren) and the crenarchaeol'/crenarchaeol ratio. The \%cren-inferred lake level identified a single lowstand (15.414.4 kacal BP), while the crenarchaeol'/crenarchaeol ratio suggests a relatively lower lake level between 15.4-14.4 and 12.5-11.7 kacalBP, corresponding to periods of weakened ISM during the Heinrich 1 and Younger Dryas cold event. A filtered TetraEther indeX consisting of 86 carbon atoms (TEX 86 index) revealed that lake surface temperature was similar to present-day values during the last deglacial period and suggests a substantial warming of $\sim 4{ }^{\circ} \mathrm{C}$ from the early Holocene to the mid-Holocene. Our paleotemperature record is generally consistent with other records in southwest China, suggesting that the distribution of isoGDGTs in Lake Cheng-
\end{abstract}

hai sediments has potential for quantitative paleotemperature reconstruction.

\section{Introduction}

Precipitation variation in the Indian summer monsoon (ISM) region has a strong influence over ecosystem function, water availability and economic security across the region (Sinha et al., 2011, 2015; Ljungqvist et al., 2016). As a result, scientific interest has been stimulated in understanding the underlying forcing mechanisms behind climate variability in the ISM region on a range of timescales, in order to better predict future monsoonal variations. Over the past 2 decades, climate evolution in the ISM region since the Last Glacial Maximum has been reconstructed from various paleoclimatic archives, including speleothems and marine or lacustrine sediments (Dykoski et al., 2005; Rashid et al., 2007; Govil and Divakar Naidu, 2011; Saraswat et al., 2013; Contreras-Rosales et al., 2014; Q. Wang et al., 2014; Dutt et al., 2015; Wu et al., 2015; Kathayat et al., 2016; Zhang et al., 2017a, b, 2018, 2019; Li et al., 2018; Sun et al., 2019). These studies provide evidence of changes in ISM precipitation on orbital and millennial timescales, with a weakened ISM occurring dur- 
ing cold events and strengthened ISM occurring during warm intervals.

In addition to precipitation, temperature is an important climatic factor, due to its significant effects on evaporation and regional hydrological cycle. There remains a lack of quantitative reconstructions of terrestrial temperature from the ISM region (Shen et al., 2006; Zhang et al., 2017a, 2019; Wu et al., 2018; Feng et al., 2019; Ning et al., 2019; Tian et al., 2019). During the last deglaciation-Holocene transition, the climate of high latitudes in the Northern Hemisphere is punctuated by three abrupt, millennial-scale events: the Heinrich 1 (H1) cold event, the Bølling-Allerød (BA) warm period and the Younger Dryas (YD) cooling (Alley and Clark, 1999). These intervals are attributed to a variety of mechanisms including changes to orbitally controlled insolation, ice sheet extent, oceanic circulation and atmospheric greenhouse concentrations (Alley and Clark, 1999). The recent quantitative summer temperature proxy based on pollen and chironomids from southwest China has been developed to address the response of long-term temperature to the highlatitude climate changes (Zhang et al., 2017a, 2019; Wu et al., 2018). However, the magnitude of these temperature variations is not consistent, and further studies are required.

Glycerol dialkyl glycerol tetraethers (GDGTs) have been widely used for the quantitative reconstruction of terrestrial paleotemperature during the Quaternary due to the fact that they are ubiquitous in soils and lacustrine sediments (Blaga et al., 2013; M. Wang et al., 2017; Zheng et al., 2018; Ning et al., 2019; Tian et al., 2019). Isoprenoid GDGTs (isoGDGTs), comprising acyclic or ring-containing isoprenoidal biphytanyl carbon chains, are a suit of membrane lipids produced by some species of archaea, such as Euryarchaeota and Thaumarchaeota (Schouten et al., 2013). IsoGDGTs containing 0 to 3 cyclopentane moieties (isoGDGTs 0-3, Fig. S1 in the Supplement) are common isoGDGTs with a large range of biological sources (Schouten et al., 2013). For example, Thaumarchaeota were the dominant biological source of GDGT-0 in Lake Lucerne from Switzerland (Blaga et al., 2011), while GDGT-0 in Lake Challa surface sediments might predominantly derive from archaea residing in the deeper, anoxic water column, such as group 1.2 and marine benthic group $\mathrm{C}$ group of the Crenarchaeota, and the Halobacteriales of the Euryarchaeota (Sinninghe Damsté et al., 2009). Methanogenic and methanotrophic archaea can also be two important sources of GDGT-0 within the water column and sediment (Blaga et al., 2009; Powers et al., 2010). In contrast, crenarchaeol and its regioisomer, crenarchaeol' (Fig. S1), are considered to be produced specifically by mesophilic Thaumarchaeota in aquatic environments (Schouten et al., 2002, 2013; Blaga et al., 2009; Kim et al., 2010; Powers et al., 2010). On this basis, the ratio of GDGT-0/crenarchaeol has been proposed to evaluate the influence of Thaumarchaeota on the distribution of isoGDGTs in lacustrine sediments, and the ratio typically varies between 0.2 and 2 in Thaumarchaeota (Schouten et al., 2002; Blaga et al., 2009).

Thaumarchaeota have a physiological mechanism to increase the weighted average number of cyclopentane rings in their membrane lipids with growth temperature (Schouten et al., 2002). Thus the TetraEther indeX consisting of 86 carbon atoms $\left(\mathrm{TEX}_{86}\right.$ index), which represents the relative number of cyclopentane moieties in isoGDGT molecules derived from aquatic Thaumarchaeota, has great potential for use as a paleotemperature proxy in the marine environment and large lakes (Tierney et al., 2008; Berke et al., 2012; Blaga et al., 2013; Wang et al., 2015). However, the index may not be a reliable proxy for past temperature in small lakes due to substantial amounts of soil and/or methanogenic archaeal isoGDGTs identified in the same lacustrine sediment and also due to variability in the depth of isoGDGT production in aquatic ecosystems (Blaga et al., 2009; Powers et al., 2010; Sinninghe Damsté et al., 2012a).

It has also been shown that crenarchaeol' is only present in low abundance in most Thaumarchaeota except for the group I.1b Thaumarchaeota, where it is one of the major isoGDGTs (Kim et al., 2012; Sinninghe Damsté et al., 2012b). The crenarchaeol'/crenarchaeol ratios for enrichment cultures of group I.1a aquatic Thaumarchaeota are typically 0.01-0.04; however, for group I.1b Thaumarchaeota enriched from soils the crenarchaeol'/crenarchaeol ratios are around 0.21 and substantially higher (Pitcher et al., 2011; Sinninghe Damsté et al., 2012a). In addition, a likely group I.1b Thaumarchaeota population inhabiting the subsurface water column near the anoxic-suboxic boundary was found in Lake Malawi, but the total production of isoGDGTs by this group appears to be much lower than for the surfacedwelling Thaumarchaeota (Meegan Kumar et al., 2019).

In addition, aquatic Thaumarchaeota are nitrifiers that prefer to live above the oxycline of relatively deep lakes, as has been observed by a range of lipid-biomarker- and DNAbased investigations of vertical changes in archaea communities in lake water columns (Sinninghe Damsté et al., 2009; Blaga et al., 2011; Schouten et al., 2012; Buckles et al., 2013; Meegan Kumar et al., 2019). Some Thaumarchaeota are thought to be suppressed by a high light level, which consequently might also inhibit their ability to thrive near the surface of lakes (Schouten et al., 2013). Further, Thaumarchaeota are chemoautotrophic and thrive predominantly near the oxycline in stratified lakes, mainly due to the release of ammonia derived from descending particulate organic matter that is recycled primarily by photoautotrophs or heterotrophs in the photic zone (Tierney et al., 2010). Consequently, the proportion of crenarchaeol in isoGDGTs (\%cren) has been suggested as a lake-level proxy (H. Wang et al., 2014, 2017, 2019). However, it has also been suggested that mixing the water column will be much more frequent at lowstand conditions, and therefore periodically or permanently oxic, high nutrient availability water and enhanced nitrogen cycling would be likely to result in a relatively higher 
production of crenarchaeol (Filippi and Talbot, 2005; Sinninghe Damsté et al., 2012a).

In this study, we present an isoGDGT record spanning the last deglaciation-Holocene transition from Lake Chenghai in the southwest China. Our stable oxygen isotope $\left(\delta^{18} \mathrm{O}\right)$ record of authigenic carbonates from Lake Chenghai previously revealed that drought events occurred from 15.6 to $14.4 \mathrm{kacal} \mathrm{BP}$ and 12.5 to $11.7 \mathrm{kacal} \mathrm{BP}$ corresponding to the H1 and YD event (Sun et al., 2019). The present study aims were to (1) identify sources of isoGDGTs in Lake Chenghai sediments and their linkage, if any, with lake-level variation; (2) test the reliability of isoGDGT-based proxies as temperature indicators, by comparing our results with other paleoenvironmental records from adjacent areas, and explore the possible mechanisms driving temperature variations during the last deglaciation-Holocene transition in southwestern China.

\section{Materials and methods}

\subsection{Regional setting}

Lake Chenghai $\left(26^{\circ} 27^{\prime}-26^{\circ} 38^{\prime} \mathrm{N}, \quad 100^{\circ} 38^{\prime}-100^{\circ} 41^{\prime} \mathrm{E}\right.$; Fig. 1a) is a tectonic lake located in the northwestern part of Yunnan Province (Wang and Dou, 1998). The current water surface elevation is $\sim 1500 \mathrm{~m}$ above sea level (a.s.l.), and the maximum water depth is $\sim 35 \mathrm{~m}$. The lake is hydrologically closed at present, with a surface area of $\sim 77 \mathrm{~km}^{2}$ and a catchment of $\sim 318 \mathrm{~km}^{2}$ (Wu et al., 2004). However, Lake Chenghai was linked to the Jinsha River via the Haikou River before a dam at an elevation of $\sim 1540 \mathrm{~m}$ a.s.l. was constructed on its southern side at $\sim 0.3 \mathrm{kacalBP}$ (Wang and Dou, 1998). The annual mean lake surface temperature (LST) is $\sim 16^{\circ} \mathrm{C}$ (Wan et al., 2005). In summer, the lake becomes thermally stratified, with the thermocline at between 10 to $20 \mathrm{~m}$ (Lu, 2018). Despite a relatively large catchment, the lake level is mainly maintained by direct precipitation and groundwater, with a total dissolved solid load of $\sim 1 \%$ o and $\mathrm{pH}$ of $\sim 8$ (Wan et al., 2005). The lake is eutrophic with a total phosphate concentration of $0.05 \mathrm{mgL}^{-1}$ and total nitrogen concentration of $0.89 \mathrm{mg} \mathrm{L}^{-1}$ (K. Li et al., 2019). Topsoil types are lateritic red earths and mountain red brown soils in the catchment (Wang and Dou, 1998). The Lake Chenghai region is mainly affected by a warm-humid monsoonal airflow from the tropical Indian Ocean from June to September and by the southern branch of the Northern Hemisphere westerly jet between October and May (Wang and Dou, 1998). The mean annual air temperature (MAAT) is $\sim 14{ }^{\circ} \mathrm{C}$, the mean annual precipitation is $\sim 660 \mathrm{~mm}$ with $80 \%$ falling between June and September (the Yongsheng meteorological station $26.68^{\circ} \mathrm{N}, 100.75^{\circ} \mathrm{E}$; elevation of $2130 \mathrm{~m}$ a.s.l.).
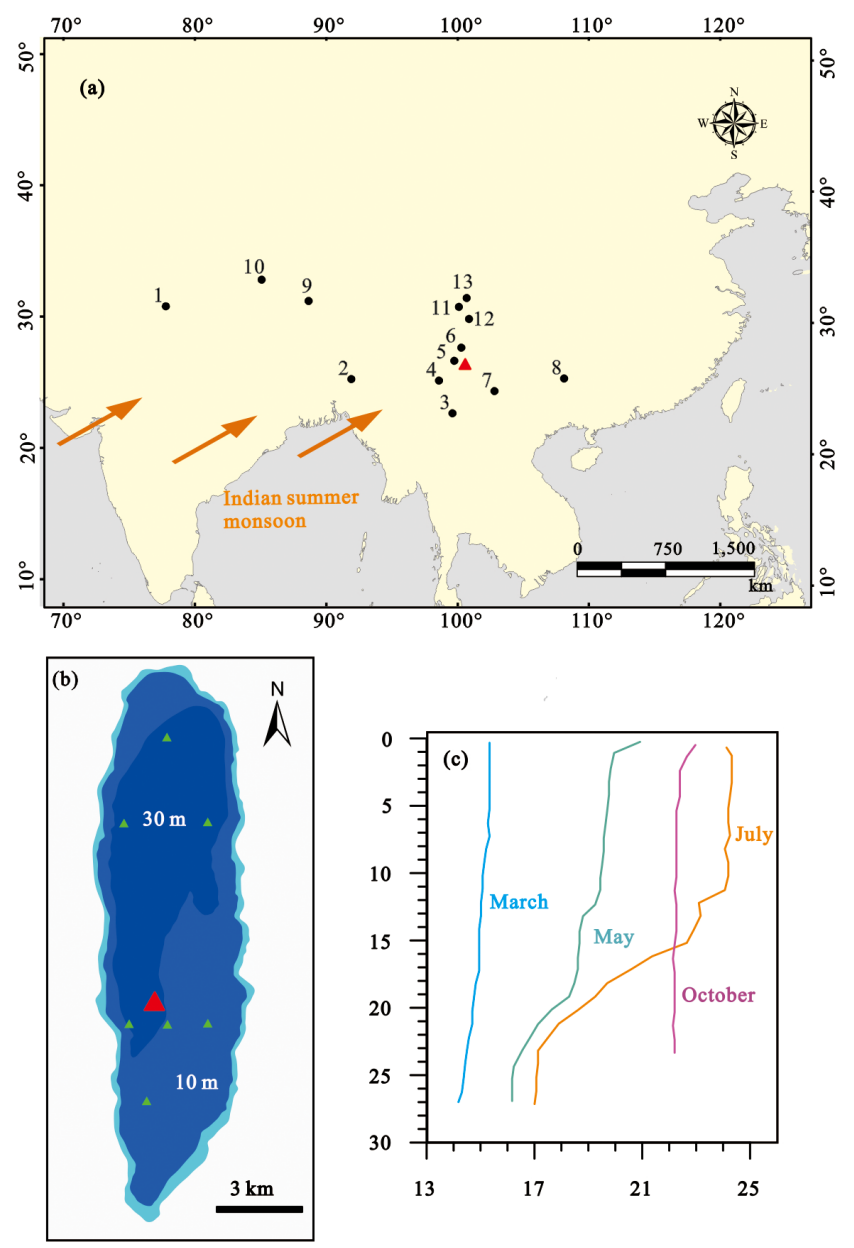

Figure 1. (a) Map showing the location of Lake Chenghai in southwest China (red triangle) and other sites (circles) mentioned in the text: (1) Bittoo Cave (Kathayat et al., 2016); (2) Mawmluh Cave (Dutt et al., 2015); (3) Lake Ximenglongtan (Ning et al., 2019); (4) Lake Tengchongqinghai (Zhang et al., 2017b; Li et al., 2018; Tian et al., 2019); (5) Lake Tiancai (Zhang et al., 2017a, 2019); (6) Lake Lugu (Wang et al., 2014); (7) Lake Xingyun (Wu et al., 2015, 2018); (8) Dongge Cave (Dykoski et al., 2005); (9) Nam Co (Günther et al., 2015); (10) Dangxiong Co (Ling et al., 2017); (11) Lake Yidun (Shen et al., 2006); (12) Lake Wuxu (Zhang et al., 2016); (13) Lake Muge (Ni et al., 2019). (b) The red triangle indicates the location of core $\mathrm{CH} 2016$ in Lake Chenghai, while green triangles indicate the locations of surface samples. (c) The vertical variation in Lake Chenghai water temperature in March, May, July and October (Lu, 2018).

\subsection{Sampling and dating}

In summer 2016, an $874 \mathrm{~cm}$ long sediment core (CH2016) was retrieved using a UWITEC coring platform system with a percussion corer in $30 \mathrm{~m}$ of water depth $\left(26^{\circ} 33^{\prime} 29.4^{\prime \prime} \mathrm{N}\right.$, $\left.100^{\circ} 39^{\prime} 6.7^{\prime \prime} \mathrm{E}\right)$. Each section of the core was split lengthways, photographed and then sectioned at a $1 \mathrm{~cm}$ interval in the laboratory, with the samples stored at $4{ }^{\circ} \mathrm{C}$ until analysis. The chronology was established using accelerator mass spec- 


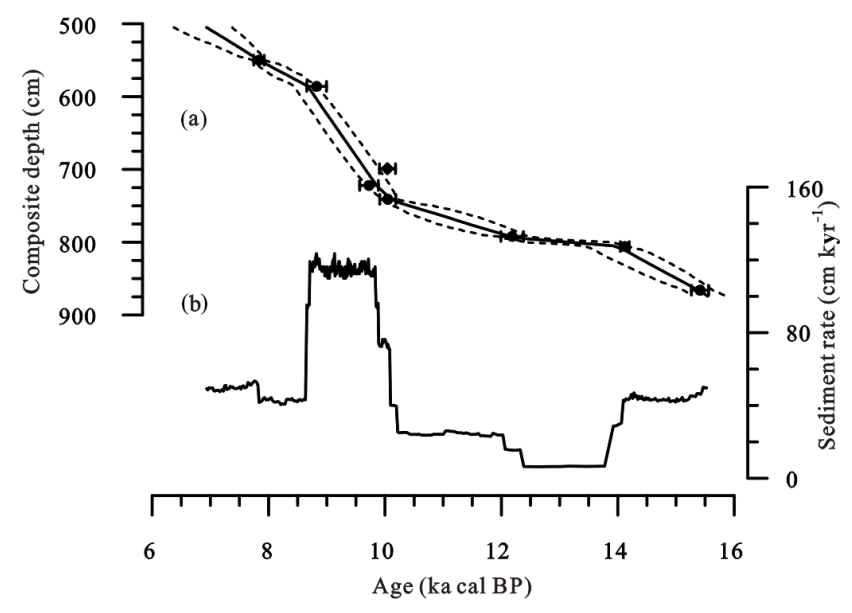

Figure 2. (a) Age-depth model for the Lake Chenghai sediment core produced using Bacon software (Blaauw and Andres Christen, 2011) from Sun et al. (2019). Dotted lines indicate the $95 \%$ confidence range and the solid line indicates the weighted mean ages for each depth; error bars indicate the standard deviation range $(2 \sigma)$ of the calibrated radiocarbon dates. (b) Estimated sedimentation rate (Sun et al., 2019).

trometry (AMS) ${ }^{14} \mathrm{C}$ dating of eight terrestrial plant macrofossils and charcoal (Sun et al., 2019). The radiocarbon analyses were performed at the Beta Analytic Radiocarbon Dating Laboratory in Miami, USA. The age model was developed utilising Bacon, implemented in $\mathrm{R} 3.1 .0$ at $5 \mathrm{~cm}$ intervals (Blaauw and Andres Christen, 2011; R Development Core Team, 2013). All AMS ${ }^{14} \mathrm{C}$ dates were calibrated to calendar years before present (0BP : 1950) using the program Calib 7.1 and the IntCal13 calibration data set (Reimer et al., 2013). The basal mean weighted age is $\sim 15.6 \mathrm{kacalBP}$ (Fig. 2).

\subsection{Lipid extraction and analysis}

A total of 102 freeze-dried samples at $4 \mathrm{~cm}$ interval were collected for GDGT analysis over the last deglaciationHolocene transition. The sampling resolution was increased to $1 \mathrm{~cm}$ between 792 and $806 \mathrm{~cm}$, due to the low sedimentation rate observed in this section. In addition, seven surface (the top $2 \mathrm{~cm}$ ) sediments covering the whole lake sampled in 2014 were also analysed. Lipid extraction was undertaken according to the procedures in Feng et al. (2019). A $\sim 4 \mathrm{~g}$ aliquot of each sample was extracted ultrasonically (4 times) with a mixture of dichloromethane and methanol $(9: 1, v / v)$. The supernatants were condensed and saponified at room temperature for $12 \mathrm{~h}$ with a $1 \mathrm{M}$ $\mathrm{KOH} /$ methanol solution. The neutral fractions were then separated into apolar and polar fractions on a silica gel column, using $n$-hexane and methanol, respectively. The polar fraction containing the GDGTs was concentrated and filtered through $0.45 \mu \mathrm{m}$ polytetrafluoroethylene syringe filters using $n$-hexane/isopropanol $(99: 1 v / v)$ and then dried under $\mathrm{N}_{2}$.
GDGTs were analysed using an Agilent 1260 series high-performance liquid-chromatography-atmosphericpressure chemical-ionisation-mass spectrometer (HPLCAPCI-MS), following the procedure of Yang et al. (2015) at the Institute of Tibetan Plateau Research, Chinese Academy of Sciences. Briefly, the GDGTs were separated using three silica columns in tandem $(100 \mathrm{~mm} \times 2.1 \mathrm{~mm}, 1.9 \mu \mathrm{m}$; Thermo Fisher Scientific, USA), maintained at $40^{\circ} \mathrm{C}$. The elution gradients were $84 \% n$-hexane (A): $16 \%$ ethyl acetate (B) for $5 \mathrm{~min}, 84 / 16$ to $82 / 18 \mathrm{~A} / \mathrm{B}$ for another $60 \mathrm{~min}$, then to $100 \% \mathrm{~B}$ for $21 \mathrm{~min}$ and kept for $4 \mathrm{~min}$, followed by a return to $84 / 16 \mathrm{~A} / \mathrm{B}$ for $30 \mathrm{~min}$. The total flow rate of pump A and pump $\mathrm{B}$ was maintained at $0.2 \mathrm{~mL} \mathrm{~min}^{-1}$. The APCIMS conditions were vaporiser pressure $60 \mathrm{psi}$, vaporiser temperature $400{ }^{\circ} \mathrm{C}$, drying gas flow $6 \mathrm{~L} \mathrm{~min}^{-1}$ and temperature $200^{\circ} \mathrm{C}$, capillary voltage $3500 \mathrm{~V}$ and corona current $5 \mu \mathrm{A}$ $(\sim 3200 \mathrm{~V})$. Selected ion monitoring (SIM) mode was performed to target specific $m / z$ values for each GDGT compound, including 1302 (GDGT-0), 1300 (GDGT-1), 1298 (GDGT-2), 1296 (GDGT-3) and 1292 (crenarchaeol and crenarchaeol'). The results are presented as the fraction of the sum of the isoGDGTs based on the integration of the peak areas of the $[\mathrm{M}+\mathrm{H}]^{+}$ions.

\subsection{Index calculation and temperature reconstruction}

The percentage of each isoGDGT $(X)$ was calculated according to the following equation:

$$
\begin{aligned}
\% X & =X /(\text { GDGT- } 0+\text { GDGT- } 1+\text { GDGT-2 }+ \text { GDGT- } 3 \\
& \left.+ \text { crenarchaeol }+ \text { crenarchaeol }^{\prime}\right) .
\end{aligned}
$$

The $\mathrm{TEX}_{86}$ index was defined by Schouten et al. (2002) as follows:

$$
\begin{aligned}
\text { TEX }_{86} & =\left(\text { GDGT- }+ \text { GDGT-3 + } \text { crenarchaeol' }^{\prime}\right) /(\text { GDGT-1 } \\
& \left.+ \text { GDGT- }+ \text { GDGT-3 }+ \text { crenarchaeol }^{\prime}\right) .
\end{aligned}
$$

TEX $_{86}$-inferred LST was calculated using the global lake calibration of Castañeda and Schouten (2015):

$\mathrm{LST}=49.03 \times \mathrm{TEX}_{86}-10.99$

$\left(r^{2}=0.88, n=16, \mathrm{RMSE}=3.1^{\circ} \mathrm{C}\right)$.

\section{Results}

The isoGDGT compositions varied greatly in Lake Chenghai sediments. As illustrated in Fig. 3, GDGT-0 is the most abundant isoGDGT composition of the surface sediments. The relative abundance of GDGT- 0 (\%GDGT- 0 ) ranged from 72.6 to 94.4 with a mean of $89.3 \%$; the \%cren values varied from $3.8 \%-18.4 \%$ with a mean of $7.7 \%$. The ratios of 

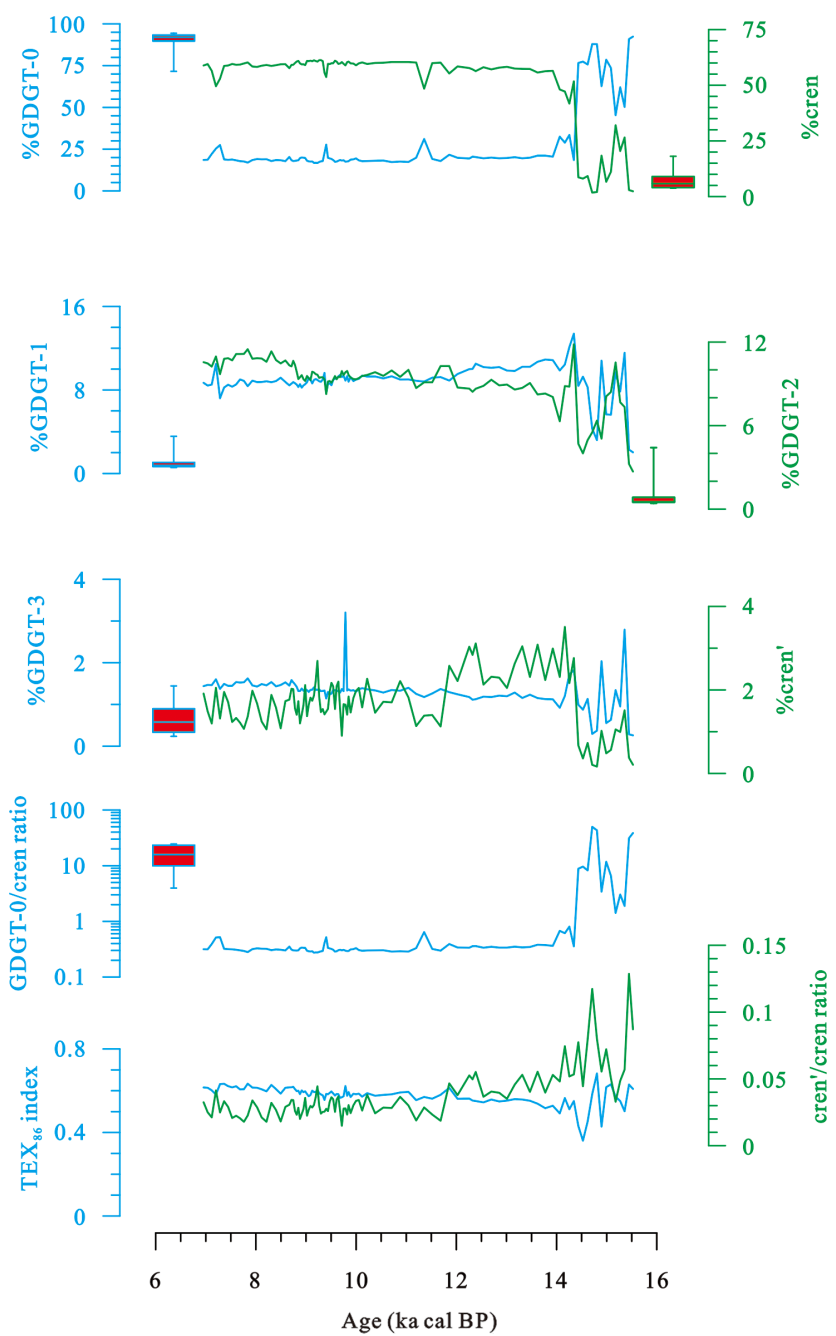

Figure 3. Variations in the relative isoGDGT distribution and isoGDGTs-based proxies of the Lake Chenghai sediment core. The box-whisker plots indicate the values from surface sediments.

GDGT-0/crenarchaeol were from 4.0 to 24.5 with a mean of 15.5. The average values of GDGT-1, GDGT-2 and GDGT-3 relative abundance were $1.2 \%, 1.1 \%$ and $0.7 \%$, respectively. The crenarchaeol' occurred in only low abundance, close to the detection limit, and therefore $\mathrm{TEX}_{86}$ values could not be calculated for these surface sediments.

The \%cren values ranged between $2.4 \%$ and $61.3 \%$ with a mean of $52.4 \%$ in the core $\mathrm{CH} 2016$ (Fig. 3). The \%cren values were relatively low and highly variable during 15.4 14.4 kacal BP, ranging between $1.8 \%$ and $32.0 \%$, with a mean of $11.6 \%$. By contrast, the values were relatively stable during 14.4-7.0 kacalBP, ranging between $41.8 \%$ and $61.3 \%$ with a mean of $58.3 \%$. The relative abundances of crenarchaeol' had a mean of $1.7 \%$ (Fig. 3). The ratios of crenarchaeol' / crenarchaeol were highly variable during 15.4-14.4 kacalBP with a mean of 0.07 (Fig. 3). After this time, the values gradually decrease during the 14.4-
$11.7 \mathrm{kacal}$ BP time interval with a minor increase between 12.5 and $11.7 \mathrm{kacalBP}$, where the ratio averaged 0.05 . The

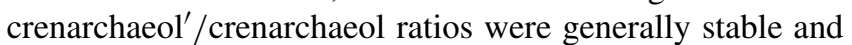
fluctuated around 0.03 during the period $11.8-7.0 \mathrm{kacal} \mathrm{BP}$.

The relative abundances of GDGT-0 (\%GDGT- 0 ) showed a significant negative correlation with the \%cren in the core CH2016 $(r=0.99, p<0.001)$. The \%GDGT-0 values had a mean of $74.0 \%$ between 15.4 and $14.4 \mathrm{kacal} \mathrm{BP}$ and a mean of $19.6 \%$ during the $14.4-7.0 \mathrm{kacal}$ BP interval (Fig. 3). The values of GDGT-0/crenarchaeol were generally $>2$ during the period 15.4-14.4 kacal BP, ranging from 1.4 to 49.9 with a mean of 16.7, and all were $<2$ from 14.4 to $7.0 \mathrm{kacalBP}$ (Fig. 3). The relative abundance of GDGT-1, GDGD-2 and GDGT-3 was generally low in the sediments, with means of 8.9, 9.2 and 1.3, respectively (Fig. 3).

The $\mathrm{TEX}_{86}$ values were also highly variable during 15.4$14.4 \mathrm{kacal}$ BP period, ranging between 0.36 and 0.68 with a mean of 0.54 (Fig. 3). Thereafter, the values generally followed an increasing trend, ranging between 0.49 and 0.63 with a mean of 0.58 .

\section{Discussion}

\subsection{Provenance of isoGDGTs}

In order to evaluate the potential sources of isoGDGTs in Lake Chenghai sediments, we plotted a ternary diagram (Fig. 4) to compare the distribution patterns of GDGT-0, crenarchaeol, and the sum of GDGT-1, GDGT-2, GDGT-3 and crenarchaeol' ("TEX 86 " GDGT) among our samples, previously published Chinese soils and global marine sediments compiled by Yao et al. (2019), and previously published Chinese lacustrine surface sediments results (Günther et al., 2014; Dang et al., 2016; Hu et al., 2016; J. Li et al., 2016, 2019; Yao et al., 2019; Wang et al., 2020). In Lake Chenghai surface sediments, GDGT-0 is the predominant component among the isoGDGTs, consistent with most previous studies of lacustrine sediments (Blaga et al., 2009; Dang et al., 2016; J. Li et al., 2019; Yao et al., 2019; Wang et al., 2020). For example, GDGT- 0 can account for more than $90 \%$ of total isoGDGTs in shallow lake surface sediments from east China (Dang et al., 2016), 80\% in saline pond surface sediments from northeast China (Li et al., 2019) and $\sim 54 \%$ in surface sediments from the Qinghai-Tibetan Plateau (Wang et al., 2020). The values of GDGT- $0 /$ cren $>2$ in Lake Chenghai surface sediment suggest non-thaumarchaeotal isoGDGTs are also likely to be an important source in this lake system. The distribution of isoGDGTs between Chinese lacustrine surface sediments and soils was similar, and both were generally higher than that in global marine sediments and Thaumarchaeota. This line of evidence also suggests that the surface sediments could contain a significant contribution of soil isoGDGT input (J. Li et al., 2016, 2019).

The distribution of isoGDGT in Lake Chenghai sediment from 15.4 to $14.4 \mathrm{kacalBP}$ was similar to that of the sur- 
face sediments, suggesting a substantial contribution of nonThaumarchaeota during this period (Fig. 4). However, the relative abundance of GDGT- 0 significantly decreased and \%cren increased in Lake Chenghai sediments from 14.4 to $7.0 \mathrm{kacalBP}$. The plots generally overlapped with those of global marine sediments and Thaumarchaeota in the ternary diagram during this period (Fig. 4), indicating that Thaumarchaeota dominated the archaea community in Lake Chenghai during the late glacial period and the early Holocene. The observed down-core changes in crenarchaeol'/crenarchaeol ratios may be due to relatively high contributions of group I.1b Thaumarchaeota from soils during the period 15.4$11.8 \mathrm{kacalBP}$ and that these dominate the contributions of isoGDGTs derived from aquatic group I.1a Thaumarchaeota during the period from 11.8 to $7.0 \mathrm{kacal} \mathrm{BP}$.

\subsection{Assessment of isoGDGT-based lake-level proxy}

The environmental interpretation of \%cren at Lake Chenghai during the period from the last deglaciation to the early Holocene is illustrated in Fig. 5. Thaumarchaeota thrive predominantly near the oxycline in stratified lakes and are mainly suppressed by non-thaumarchaeotal archaea when the lake level is low (H. Wang et al., 2014, 2017, 2019). Thus, the abrupt increase in \%cren values is interpreted as representing an increase in lake depth in Lake Chenghai, from a lowstand during 15.4-14.4 kacal BP to a highstand period thereafter. The relatively low \%cren values during 15.4-14.4 kacalBP are consistent in timing with the $\delta^{18} \mathrm{O}$ record of authigenic carbonates derived from the same core (Sun et al., 2019), speleothem $\delta^{18} \mathrm{O}$ records from Mawmluh Cave and Bittoo Cave in north India (Dutt et al., 2015; Kathayat et al., 2016), and Donnge Cave in southwest China (Dykoski et al., 2005), which all record a substantial positive shift in $\delta^{18} \mathrm{O}$ values at that time (Fig. 5). Speleothem $\delta^{18} \mathrm{O}$ records in the ISM region are used as a rainfall amount proxy, with low $\delta^{18} \mathrm{O}$ values indicating high precipitation (Dykoski et al., 2005; Cheng et al., 2012; Dutt et al., 2015).

Low lake levels and a weakened ISM during the H1 cold event are also observed in several previous paleolimnological studies from the Yunnan Plateau, within the uncertainties of the age model. Diatom and grain-size records from Lake Tengchongqinghai show a significant decrease in acidophilous diatom species and an increase in the grain size of mineral particles from 18.5 to $15.0 \mathrm{kacalBP}$, suggesting that the climate was dry and the ISM was at its weakest since the last deglaciation (Zhang et al., 2017b; Li et al., 2018). Similarly, an increase in $>30 \mu \mathrm{m}$ grain-size particles in the late glacial sediments from Lake Xingyun reflects a period of abrupt weakening of the ISM during the $\mathrm{H} 1$ cold event because of a reduced lake level (Wu et al., 2015). In Lake Lugu, the loss of the planktonic diatoms and a switch to small Fragilaria spp. suggests a weaker stratification from 24.5 to $14.5 \mathrm{kacal} \mathrm{BP}$, which might also correspond to a low lake level at that time (Q. Wang et al., 2014).
Lake levels inferred from \%cren do not show a lowstand during the YD $(\sim 12.8-11.7 \mathrm{kacalBP})$, which is generally recognised as a period of low rainfall due to the weakening of the ISM (Dutt et al., 2015; Dykoski et al., 2005; Kathayat et al., 2016). In contrast, a low lake-level signal is observed in the $\delta^{18} \mathrm{O}$ record of authigenic carbonates from Lake Chenghai (Sun et al., 2019). Increased lake water alkalinity and a decreased lake level are also recorded in the diatom and grain-size proxy records between 12.8 and $11.1 \mathrm{kacalBP}$ of Lake Tengchongqinghai (Zhang et al., 2017b; Li et al., 2018). In addition, there is a peak of \%cren centred at $15.2 \mathrm{kacalBP}$, suggesting a centennial-scale high lake level and strengthened ISM period, which was not identified in a previous $\delta^{18} \mathrm{O}$ record of authigenic carbonates (Sun et al., 2019). The inferred high lake levels during the YD and at $\sim 15.2 \mathrm{kacalBP}$, which are inconsistent with weakened ISM inferred from other proxies, might be due to the erosion of soil organic matter into the lake during these periods (Wang et al., 2019). The crenarchaeol are relatively abundant in topsoils from southwest China, and the influence of soil input should be more significant at times of drier conditions (Yang et al., 2019). It is also worth noting that the crenarchaeol'/crenarchaeol ratios were not only relatively higher during the $\mathrm{H} 1$ cold event but also showed a minor reversal during the YD cold event. These results are consistent with group I.1b Thaumarchaeota being an important source of isoGDGTs in small lakes and in the nearshore areas of large lakes (Wang et al., 2019).

Another possibility for the different H1 and YD lake-level variation is the sensitivity of the proxy to the lake level in the case of Lake Chenghai. The $\delta^{18} \mathrm{O}$ record of authigenic carbonates from Lake Chenghai and speleothem $\delta^{18} \mathrm{O}$ records in the ISM region suggest that the weakening of the ISM during the YD was less marked than that occurring during the $\mathrm{H} 1$ event, in turn suggesting that lake levels in southwest China may have been higher during the YD than the H1 event (Dykoski et al., 2005; Dutt et al., 2015; Kathayat et al., 2016; Sun et al., 2019; Zhang et al., 2019). For the \%cren proxy, we note that the values are correlated to the logarithm of depth, suggesting that \%cren may be less sensitive to water depth variation when the lake level is relatively high and more sensitive to water depth variation when the lake level is lower (Wang et al., 2019).

The interpretation of \%cren presented here differs from that proposed for Lake Challa but is consistent with that proposed for Lake Qinghai in northwest China (Sinninghe Damsté et al., 2012a; H. Wang et al., 2014). This difference is possibly due to the different response of Thaumarchaeota in the two types of lakes because of the different mixing regime. For the small and deep Lake Challa, there is never complete mixing due to the stable stratification of the warmer water column and a lack of seasonality (Sinninghe Damsté et al., 2009). Below the oxycline nitrate levels are high, so more substantial mixing regenerates more nutrients into the surface waters, resulting a relatively higher produc- 


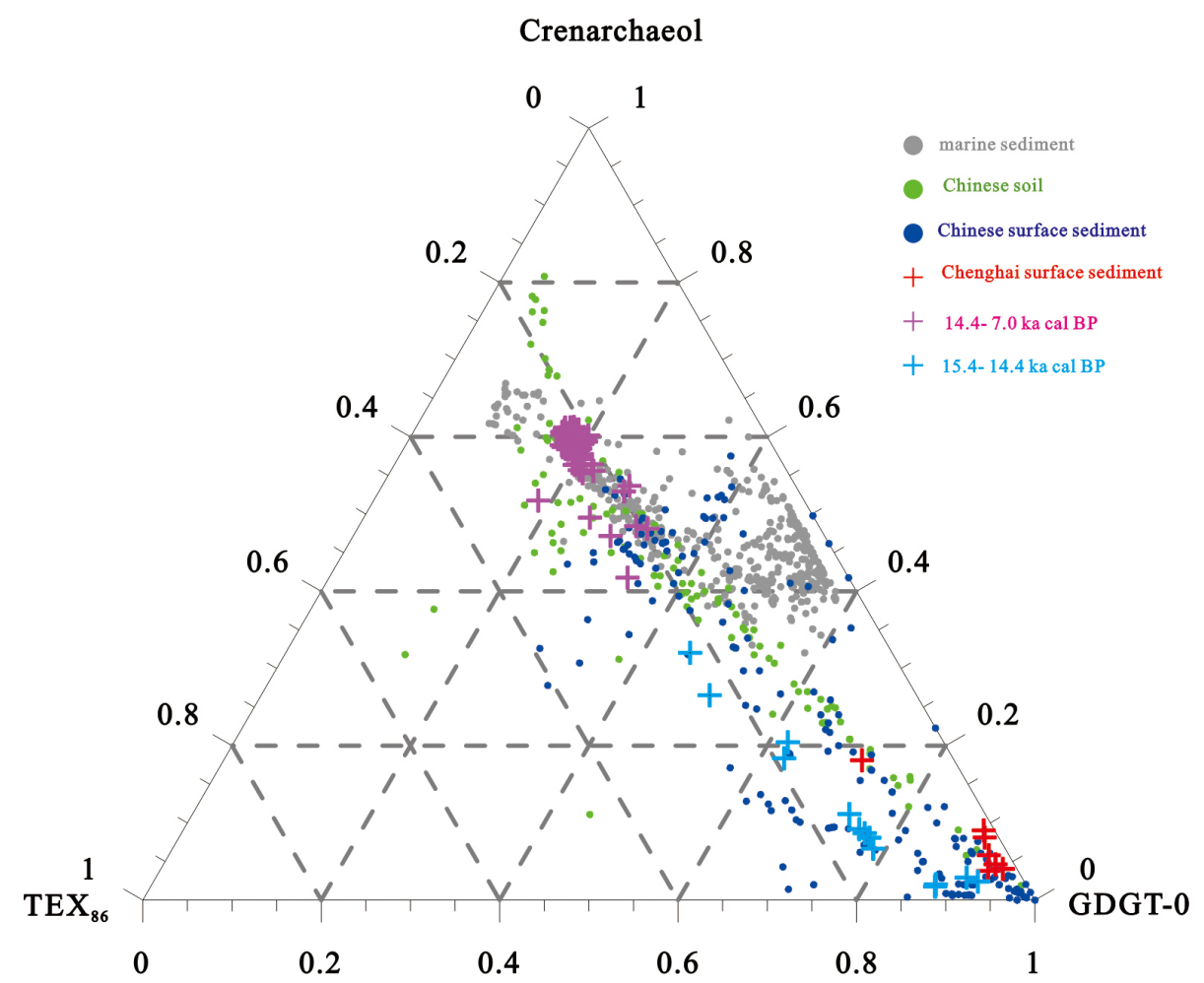

Figure 4. Ternary diagram showing the distributions of GDGT-0, crenarchaeol, "TEX 86 " GDGTs in surface and core sediments from Lake Chenghai, global marine sediments (Kim et al., 2010), published Chinese soils compiled by Yao et al. (2019), and Chinese lacustrine surface sediments (Günther et al., 2014; Dang et al., 2016; Hu et al., 2016; Li et al., 2016, 2019; Yao et al., 2019; Wang et al., 2020).

tion of crenarchaeol when the lake level is substantially reduced (Sinninghe Damsté et al., 2012a). In contrast, Lake Chenghai and Lake Qinghai are seasonally mixed lakes, and the vertical change in nutrients may be relatively small. In addition, terrestrial nutrient input would be a shorter timescale mechanism explaining the relationship between ISM index and \%cren values (H. Wang et al., 2014). Less nutrient input due to a weakened ISM during the $\mathrm{H} 1$ event would likely suppress the growth of Thaumarchaeota and reduce the production of crenarchaeol.

\subsection{Warming in the last deglaciation-Holocene transition}

The application of the $\mathrm{TEX}_{86}$-based paleotemperature calibration depends critically on the assumption that the isoGDGTs used for the calculation of $\mathrm{TEX}_{86}$ values have mainly been derived from group I.1a in the water column (Blaga et al., 2009; Castañeda and Schouten, 2011; Powers et al., 2010; Sinninghe Damsté et al., 2012a). Since the influence of methanogenic archaea in the water column or archaea in the catchment soils has been recognised as significant, Lake Chenghai sediments with crenarchaeol'/crenarchaeol ratios $>0.04$ and/or a GDGT-0/crenarchaeol ratio $>2$ are excluded from the discussion below (Powers et al., 2010; Castañeda and Schouten, 2015). The ratio of branched
GDGTs to isoGDGTs (BIT) should be $<0.5$ if the TEX 86- $^{-}$ temperature calibration is applied in previous studies because the values are generally $>0.90$ in soils, whereas values are close to zero for sediments from large lakes (Powers et al., 2004; Weijers et al., 2006). However, recent studies of a wide variety of lakes have suggested that at least some of the branched GDGTs can be produced in situ in the lake (Blaga et al., 2010; Tierney et al., 2010; Pearson et al., 2011; Hu et al., 2016; Dang et al., 2018; Russell et al., 2018). Therefore, in situ production of branched GDGTs in Lake Chenghai cannot be fully excluded, and therefore the ratio of BIT was ignored in this study. Overall, 74 samples remain that have isoGDGT distributions consistent with their dominant source being the aquatic Thaumarchaeota, most of these being from the time interval between 11.7 and $7.0 \mathrm{kacalBP}$ and only a few from the last deglaciation $(n=6)$. Using Eq. (4) developed by Castañeda and Schouten (2015) to calculate mean LST yielded LST values from 14.3 to $20.1^{\circ} \mathrm{C}$, with a mean of $18.0^{\circ} \mathrm{C}$ (Fig. 6).

LST was $\sim 15.9^{\circ} \mathrm{C}$ during the last deglacial period, a temperature approaching the $16^{\circ} \mathrm{C}$ observed in the present Lake Chenghai. Considering that the TEX $86^{-b a s e d ~ L S T ~ t r a n s f e r ~}$ function has an RMSE of $3.1^{\circ} \mathrm{C}$, this result is consistent with other recent reconstructed MAAT in southwest China, which show that the temperatures during the last deglaciation were generally similar to the present-day values. For exam- 


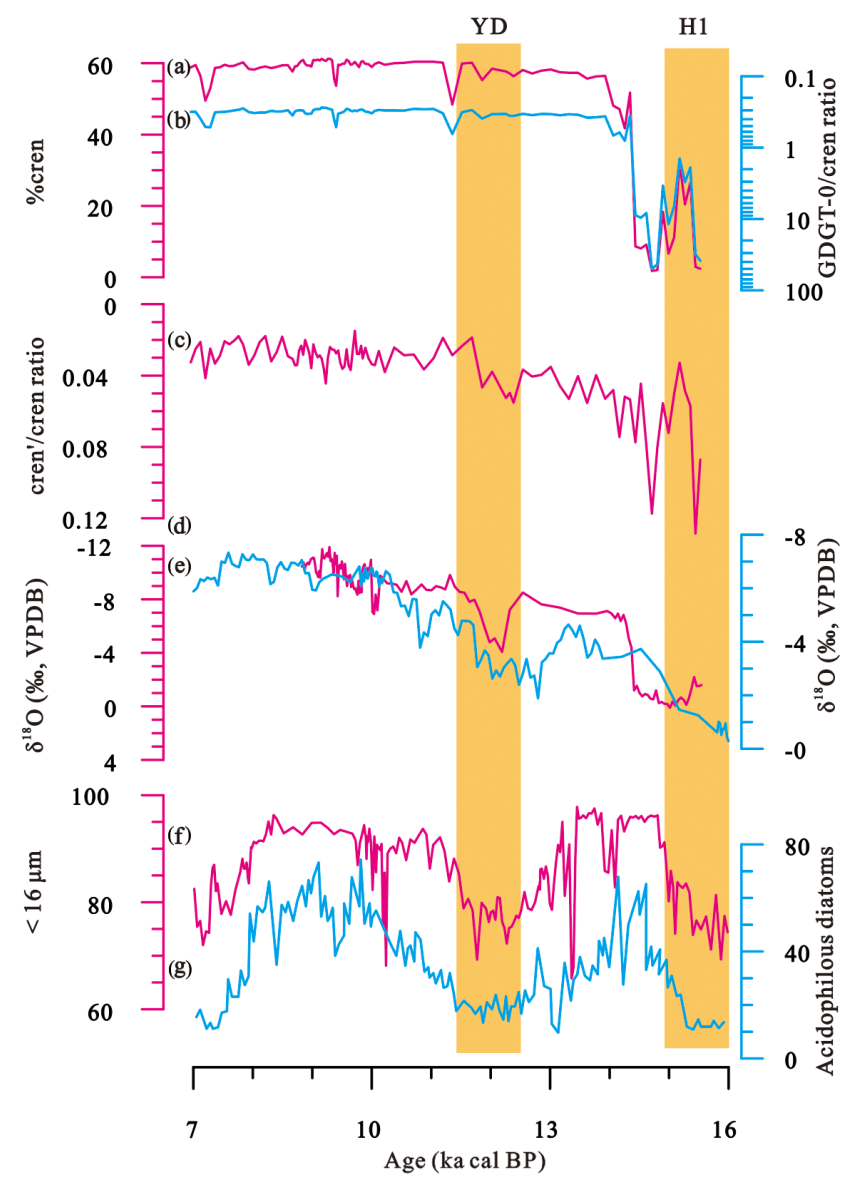

Figure 5. Comparison of the isoGDGT-based lake-level record from Lake Chenghai (a-c) with the $\delta^{18} \mathrm{O}$ record of carbonate finer in grain size than $63 \mu \mathrm{m}$ from Lake Chenghai (d, Sun et al., 2019), the stalagmite $\delta^{18} \mathrm{O}$ records from Mawmluh Cave in northeast Indian (e, Dutt et al., 2015); grain-size and diatom record from Lake Tengchongqinghai (f and g, Zhang et al., 2017b; Li et al., 2018). The shading is utilised to represent "cold" events in the North Atlantic.

ple, the MAAT inferred from branched GDGTs from Lake Tengchongqinghai in southwest China increased episodically from 12.0 to $14.0^{\circ} \mathrm{C}$ between 19.2 and $10.0 \mathrm{kacalBP}$, where the modern mean annual temperature is $14.7^{\circ} \mathrm{C}$ (Tian et al., 2019). The TEX $\mathrm{X}_{86}$-based deglacial LST and MAAT inferred from branched GDGTs from Nam Co in the south Tibetan Plateau also reported values similar to the present day (Günther et al., 2015). In contrast, the July air temperature derived from the chironomid record from Lake Tiancai and pollen record from Lake Yidun showed that the climate during the deglacial period was $\sim 2-3{ }^{\circ} \mathrm{C}$ cooler relative to today (Shen et al., 2006; Zhang et al., 2019). The amplitudes of reconstructed terrestrial temperatures change in the Indian summer monsoon region are generally consistent with those from the tropical Indian Ocean. Although estimates of sea surface temperatures (SSTs) in the Andaman Sea and Bay of Bengal were variable, the cooling relative to today ranged from 1 to


Figure 6. A comparison of $\mathrm{TEX}_{86}$-based lake surface temperature of Lake Chenghai (a) with other paleotemperature records from the ISM region. (b) Mean annual temperature based on branched GDGTs from Lake Ximenglongtan (blue line, Ning et al., 2019) and Lake Tengchongqinghai (black line, Tian et al., 2019); (c) alkenonebased mean annual temperature at Lake Dangxiong (blue line, Ling et al., 2017) and $\mathrm{TEX}_{86}$-based lake surface temperature of Nam Co from the southern Tibetan Plateau (black line, Günther et al., 2015); (d) July temperature reconstructed from pollen record from Lake Xingyun (blue line, Wu et al., 2018) and subfossil chironomids from Lake Tiancai (black line, Zhang et al., 2017a, 2019); and (e) SSTs in the Andaman Sea and Bay of Bengal (Rashid et al., 2007; Govil and Divakar Naidu, 2011; Gebregiorgis et al., 2016).

$4{ }^{\circ} \mathrm{C}$ (Rashid et al., 2007; MARGO Project Members, 2009; Govil and Naidu, 2011; Gebregiorgis et al., 2016).

Following the YD cold event, LST at Lake Chenghai ranged from 16.2 to $20.1^{\circ} \mathrm{C}$ with an increasing trend, and the middle Holocene was generally warmer than the early Holocene (11.7-8.2 kacal BP). In the Indian summer monsoon region, the reconstructed MAAT using the branched 
GDGT calibration from Lake Ximenglongtan remained at $\sim 12.5^{\circ} \mathrm{C}$ from 9.4 to $7.6 \mathrm{kacalBP}$ and then experienced a rapid warming to $13.8^{\circ} \mathrm{C}$ from 7.6 to $5.5 \mathrm{kacalBP}$ (Ning et al., 2019). Meanwhile, the branched GDGT MAAT from Lake Tengchongqinghai also achieved its highest value at around 7.1 kacalBP (Tian et al., 2019). Similarly, summer air temperatures reconstructed from Lake Tiancai and Lake Xingyun displayed a warming trend from the early Holocene to the mid-Holocene (Zhang et al., 2017a; Wu et al., 2018). The amplitude of the absolute scale of warming is of a lower magnitude in the chironomid, pollen and branched GDGT records as compared to the $\mathrm{TEX}_{86}$-based reconstruction from Lake Chenghai. This may be due to the difference in the accuracy and precision of the proxy-based models, which also depend on the biological and seasonal sensitivity of the proxy, to constrain the absolute temperature values (Zhang et al., 2017a).

We also noted that most of the lake records from not only the Indian summer monsoon region but other parts of Asia, too, show a warming from 11.7 to $7.0 \mathrm{kacalBP}$ (Ning et al., 2019). In southwest China, Holocene summer air temperature generally follows summer isolation over the Northern Hemisphere but lags the highest value by 3-4 kyr (Berger and Loutre, 1991; Zhang et al., 2017a; Wu et al., 2018). This indicates that additional feedback between solar insolation and internal processes, such as the persistence of remnants of the Northern Hemisphere ice sheets and snow cover during the early Holocene, should be considered in explaining this discrepancy (Zhang et al., 2017a, Wu et al., 2018; Ning et al., 2019). This is evidenced by records from the Laurentide ice sheets, which were still relatively large at $\sim 11$ kacal BP, despite the occurrence of peak summer insolation (Shuman et al., 2005; Carlson et al., 2008). The melting of ice sheets from 11 to $6 \mathrm{kacalBP}$ is likely to have slowed down the Atlantic Meridional Overturning Circulation and impeded the northward shift of the Intertropical Convergence Zone (Dykoski et al., 2005). This process could further result in a relatively weakened Indian summer monsoon and a reduction in heat transported to the continent during the early Holocene (Zhang et al., 2017a). In addition, the ice sheets in the early Holocene enhanced surface albedo and reduced air temperature in the high latitudes, which likely led to enhanced westerlies transporting more cold air from the North Atlantic Ocean downward to the ISM-affected regions through its south branch flow, especially during the winter (Ning et al., 2019). A long-term winter warming trend in southwest China was revealed by the pollen record from Lake Wuxu and Muge from the southeast margin of the Qinghai-Tibetan Plateau (Zhang et al., 2016; Ni et al., 2019). In the high latitudes of the Northern Hemisphere, the early Holocene winter warming is attributed to increasing winter insolation, as well as the retreat of the Northern Hemisphere ice sheets (Baker et al., 2017; Marsicek et al., 2018). Although our LST record from Lake Chenghai has not been determined to be an indicator of summer or winter temperature, it does appear that long- term temperature evolution during the early Holocene to the mid-Holocene was driven mainly by solar insolation and the status of Northern Hemisphere ice sheets. In essence, more temperature records with unambiguous seasonal significance from different regions are needed to achieve a comprehensive understanding of Holocene temperature dynamics.

\section{Conclusions}

The record of isoGDGTs in the sediments of Lake Chenghai in southwest China presented in this study allows us to test the ability of isoGDGT-based proxies in the ISM region to reconstruct the lake level and temperature during the last deglaciation-Holocene transition. The lake-level history inferred from \%cren shows a relative lowstand of Lake Chenghai during $15.4-14.4 \mathrm{kacalBP}$, corresponding to a period of weakened ISM during the H1 cold event. The indistinct signal of lake-level variation during the YD cold event may be due to the group I.1b Thaumarchaeota being an important source of isoGDGTs, and consequently the lake level may have been low during the YD cold event. After filtering for the influence of isoGDGTs derived from soils in the surrounding catchment and non-Thaumarchaeota, the TEX 86 paleothermometry revealed that the LST of Lake Chenghai was similar to the present-day value during the last deglaciation. The lake also experienced a substantial warming of $\sim 4{ }^{\circ} \mathrm{C}$ from the early Holocene to the mid-Holocene due to the melting of the remnants of the continental ice sheets in the Northern Hemisphere, which gradually enhanced the ISM and reduced the winter westerly circulation. Overall, our results show that records of isoGDGTs in Lake Chenghai sediments have the potential for quantitative paleotemperature reconstruction once potential underlying biases are properly constrained.

Data availability. All data generated in this study can be found in the Supplement.

Supplement. The supplement related to this article is available online at: https://doi.org/10.5194/cp-16-833-2020-supplement.

Author contributions. WS and EZ designed the study; WS performed the fieldwork and lab analysis. WS and EZ led the writing of the paper; JC, JS, MIB, CZ, QJ and JS contributed to data interpretation and paper writing. All authors contributed to discussions and the writing of the paper. The authors declare that they have no competing financial interests.

Competing interests. The authors declare that they have no conflict of interest. 
Acknowledgements. We would like to thank two anonymous reviewers for their valuable suggestion on this article, as well as Rong Chen and Dongliang Ning for field assistance and laboratory analysis.

Financial support. The research was supported by the fund from the programme Global Change and Mitigation (2016YFA0600502), the National Natural Science Foundation of China (41702183 and 41572337), the Strategic Priority Research Program of Chinese Academy of Sciences (XDB40010200), and the fund from State Key Laboratory of Lake Science and Environment (2016SKL003).

Review statement. This paper was edited by Erin McClymont and reviewed by two anonymous referees.

\section{References}

Alley, R. B. and Clark, P. U.: The deglaciation of the northern hemisphere: A global perspective, Annu. Rev. Earth Planet. Sc., 27, 14-182, https://doi.org/10.1146/annurev.earth.27.1.149, 1999.

Baker, J. L., Lachniet, M. S., Chervyatsova, O., Asmerom, Y., and Polyak, V. J.: Holocene warming in western continental Eurasia driven by glacial retreat and greenhouse forcing, Nat. Geosci., 10, 430-435, https://doi.org/10.1038/ngeo2953, 2017.

Berger, A. and Loutre, M.-F.: Insolation values for the climate of the last 10 million years, Quaternary Sci. Rev., 10, 297-317, https://doi.org/10.1016/0277-3791(91)90033-Q, 1991.

Berke, M. A., Johnson, T. C., Werne, J. P., Schouten, S., and Sinninghe Damsté, J. S.: A mid-Holocene thermal maximum at the end of the African Humid Period, Earth. Planet. Sc. Lett., 351352, 95-104, https://doi.org/10.1016/j.epsl.2012.07.008, 2012.

Blaauw, M. and Andres Christen, J.: Flexible paleoclimate agedepth models using an autoregressive gamma process, Bayesian. Anal., 6, 457-474, https://doi.org/10.1214/11-BA618, 2011.

Blaga, C. I., Reichart, G.-J., Heiri, O., and Sinninghe Damsté, J. S.: Tetraether membrane lipid distributions in water-column particulate matter and sediments: a study of 47 European lakes along a north-south transect, J. Paleolimnol., 41, 523-540, https://doi.org/10.1007/s10933-008-9242-2, 2009.

Blaga, C. I., Reichart, G. J., Schouten, S., Lotter, A. F., Werne, J. P., Kosten, S., Mazzeo, N., Lacerot, G., and Damste, J. S. S.: Branched glycerol dialkyl glycerol tetraethers in lake sediments: Can they be used as temperature and $\mathrm{pH}$ proxies?, Org. Geochem., 41, 1225-1234, https://doi.org/10.1016/j.orggeochem.2010.07.002, 2010.

Blaga, C. I., Reichart, G.-J., Vissers, E. W., Lotter, A. F., Anselmetti, F. S., and Sinninghe Damsté, J. S.: Seasonal changes in glycerol dialkyl glycerol tetraether concentrations and fluxes in a perialpine lake: Implications for the use of the TEX86 and BIT proxies, Geochim. Cosmochim. Ac., 75, 6416-6428, https://doi.org/10.1016/j.gca.2011.08.016, 2011.

Blaga, C. I., Reichart, G.-J., Lotter, A. F., Anselmetti, F. S., and Sinninghe Damsté, J. S.: A TEX 86 lake record suggests simultaneous shifts in temperature in Central Europe and Greenland during the last deglaciation, Geophys. Res. Lett., 40, 948-953, https://doi.org/10.1002/grl.50181, 2013.
Buckles, L. K., Villanueva, L., Weijers, J. W. H., Verschuren, D., and Damsté, J. S. S.: Linking isoprenoidal GDGT membrane lipid distributions with gene abundances of ammonia-oxidizing Thaumarchaeota and uncultured crenarchaeotal groups in the water column of a tropical lake (Lake Challa, East Africa), Environ. Microbiol., 15, 2445-2462, https://doi.org/10.1111/14622920.12118, 2013.

Carlson, A. E., LeGrande, A. N., Oppo, D. W., Came, R. E., Schmidt, G. A., Anslow, F. S., Licciardi, J. M., and Obbink, E. A.: Rapid early Holocene deglaciation of the Laurentide ice sheet, Nat. Geosci., 1, 620-624, https://doi.org/10.1038/ngeo285, 2008.

Castañeda, I. S. and Schouten, S.: A review of molecular organic proxies for examining modern and ancient lacustrine environments, Quaternary Sci. Rev., 30, 2851-2891, https://doi.org/10.1016/j.quascirev.2011.07.009, 2011.

Castañeda, I. S. and Schouten, S.: Corrigendum to "A review of molecular organic proxies for examining modern and ancient lacustrine environments" [Quat. Sci. Rev. 30 (2011) 2851-2891], Quaternary Sci. Rev., 125, 174-176, https://doi.org/10.1016/j.quascirev.2015.07.020, 2015.

Cheng, H., Sinha, A., Wang, X., Cruz, F. W., and Edwards, R. L.: The Global Paleomonsoon as seen through speleothem records from Asia and the Americas, Clim. Dynam., 39, 1045-1062, https://doi.org/10.1007/s00382-012-1363-7, 2012.

Contreras-Rosales, L. A., Jennerjahn, T., Tharammal, T., Meyer, V., Lückge, A., Paul, A., and Schefuß, E.: Evolution of the Indian Summer Monsoon and terrestrial vegetation in the Bengal region during the past $18 \mathrm{ka}$, Quaternary Sci. Rev., 102, 133-148, https://doi.org/10.1016/j.quascirev.2014.08.010, 2014.

Dang, X., Ding, W., Yang, H., Pancost, R. D., Naafs, B. D. A., Xue, J., Lin, X., Lu, J., and Xie, S.: Different temperature dependence of the bacterial brGDGT isomers in 35 Chinese lake sediments compared to that in soils, Org. Geochem., 72-79, https://doi.org/10.1016/j.orggeochem.2018.02.008, 2018.

Dang, X. Y., Xue, J. T., Yang, H., and Xie, S. C.: Environmental impacts on the distribution of microbial tetraether lipids in Chinese lakes with contrasting $\mathrm{pH}$ : Implications for lacustrine paleoenvironmental reconstructions, Sci. China. Earth. Sci., 59, 939-950, https://doi.org/10.1007/s11430-015-5234-z, 2016.

Dutt, S., Gupta, A. K., Clemens, S. C., Cheng, H., Singh, R. K., Kathayat, G., and Edwards, R. L.: Abrupt changes in Indian summer monsoon strength during 33,800 to 5500 years B.P., Geophys. Res. Lett., 42, 5526-5532, https://doi.org/10.1002/2015GL064015, 2015.

Dykoski, C. A., Edwards, R. L., Cheng, H., Yuan, D., Cai, Y., Zhang, M., Lin, Y., Qing, J., An, Z., and Revenaugh, J.: A highresolution, absolute-dated Holocene and deglacial Asian monsoon record from Dongge Cave, China, Earth. Planet. Sc. Lett., 233, 71-86, https://doi.org/10.1016/j.epsl.2005.01.036, 2005.

Feng, X., Zhao, C., D'Andrea, W. J., Liang, J., Zhou, A., and Shen, J.: Temperature fluctuations during the Common Era in subtropical southwestern China inferred from brGDGTs in a remote alpine lake, Earth. Planet. Sc. Lett., 510, 26-36, https://doi.org/10.1016/j.epsl.2018.12.028, 2019.

Filippi, M. L. and Talbot, M. R.: The palaeolimnology of northern Lake Malawi over the last $25 \mathrm{ka}$ based upon the elemental and stable isotopic composition of sedimen- 
tary organic matter, Quaternary Sci. Rev., 24, 1303-1328, https://doi.org/10.1016/j.quascirev.2004.10.009, 2005.

Gebregiorgis, D., Hathorne, E. C., Sijinkumar, A. V., Nath, B. N., Nürnberg, D., and Frank, M.: South Asian summer monsoon variability during the last $\sim 54$ kyrs inferred from surface water salinity and river runoff proxies, Quaternary Sci. Rev., 138, 6-15, https://doi.org/10.1016/j.quascirev.2016.02.012, 2016.

Govil, P. and Divakar Naidu, P.: Variations of Indian monsoon precipitation during the last $32 \mathrm{kyr}$ reflected in the surface hydrography of the Western Bay of Bengal, Quaternary Sci. Rev., 30, 3871-3879, https://doi.org/10.1016/j.quascirev.2011.10.004, 2011.

Günther, F., Thiele, A., Gleixner, G., Xu, B., Yao, T., and Schouten, S.: Distribution of bacterial and archaeal ether lipids in soils and surface sediments of Tibetan lakes: Implications for GDGTbased proxies in saline high mountain lakes, Org. Geochem., 67, 19-30, https://doi.org/10.1016/j.orggeochem.2013.11.014, 2014.

Günther, F., Witt, R., Schouten, S., Mäusbacher, R., Daut, G., Zhu, L., Xu, B., Yao, T., and Gleixner, G.: Quaternary ecological responses and impacts of the Indian Ocean Summer Monsoon at Nam Co, Southern Tibetan Plateau, Quaternary Sci. Rev., 112, 66-77, https://doi.org/10.1016/j.quascirev.2015.01.023, 2015.

Hu, J., Zhou, H., Peng, P. A., and Spiro, B.: Seasonal variability in concentrations and fluxes of glycerol dialkyl glycerol tetraethers in Huguangyan Maar Lake, SE China: Implications for the applicability of the MBT-CBT paleotemperature proxy in lacustrine settings, Chem. Geol., 420, 200-212, https://doi.org/10.1016/j.chemgeo.2015.11.008, 2016.

Kathayat, G., Cheng, H., Sinha, A., Spötl, C., Edwards, R. L., Zhang, H., Li, X., Yi, L., Ning, Y., Cai, Y., Lui, W. L., and Breitenbach, S. F. M.: Indian monsoon variability on millennial-orbital timescales, Sci. Rep-UK., 6, 24374, https://doi.org/10.1038/srep24374, 2016.

Kim, J.-G., Jung, M.-Y., Park, S.-J., Rijpstra, W. I. C., Sinninghe Damsté, J. S., Madsen, E. L., Min, D., Kim, J.-S., Kim, G.-J., and Rhee, S.-K.: Cultivation of a highly enriched ammonia-oxidizing archaeon of thaumarchaeotal group I.1b from an agricultural soil, Environ. Microbiol., 14, 1528-1543, https://doi.org/10.1111/j.1462-2920.2012.02740.x, 2012.

Kim, J.-H., van der Meer, J., Schouten, S., Helmke, P., Willmott, V., Sangiorgi, F., Koç, N., Hopmans, E. C., and Damsté, J. S. S.: New indices and calibrations derived from the distribution of crenarchaeal isoprenoid tetraether lipids: Implications for past sea surface temperature reconstructions, Geochim. Cosmochim. Ac., 74, 4639-4654, https://doi.org/10.1016/j.gca.2010.05.027, 2010.

Li, J., Pancost, R. D., Naafs, B. D. A., Yang, H., Liu, D., Gong, L., Qiu, X., and Xie, S.: Multiple environmental and ecological controls on archaeal ether lipid distributions in saline ponds, Chem. Geol., 529, 119293, https://doi.org/10.1016/j.chemgeo.2019.119293, 2019.

Li, J. J., Pancost, R. D., Naafs, B. D. A., Yang, H., Zhao, C., and Xie, S. C.: Distribution of glycerol dialkyl glycerol tetraether (GDGT) lipids in a hypersaline lake system, Org. Geochem., 99, 113-124, https://doi.org/10.1016/j.orggeochem.2016.06.007, 2016.

Li, K., Zhou, Y., Zhou, Q., Dong, Y., Zhang, Y., Chang, J., Chen, L., and Lu, Y.: Temporal-spatial distribution of euphotic depth and its influencing factors in Lake Chenghai, Yunnan Province, China, J. Lake Sci., 31, 256-267, https://doi.org/10.18307/2019.0124, 2019.
Li, Y., Chen, X., Xiao, X., Zhang, H., Xue, B., Shen, J., and Zhang, E.: Diatom-based inference of Asian monsoon precipitation from a volcanic lake in southwest China for the last $18.5 \mathrm{ka}$, Quaternary Sci. Rev., 182, 109-120, https://doi.org/10.1016/j.quascirev.2017.11.021, 2018.

Ling, Y., Sun, Q., Zheng, M., Wang, H., Luo, Y., Dai, X., Xie, M., and Zhu, Q.: Alkenone-based temperature and climate reconstruction during the last deglaciation at Lake Dangxiong Co, southwestern Tibetan Plateau, Quaternary Int., 443, 58-69, https://doi.org/10.1016/j.quaint.2016.07.036, 2017.

Ljungqvist, F. C., Krusic, P. J., Sundqvist, H. S., Zorita, E., Brattström, G., and Frank, D.: Northern Hemisphere hydroclimate variability over the past twelve centuries, Nature, 532, 9498, https://doi.org/10.1038/nature17418, 2016.

Lu, Z.: Study on climatic and environmental changes of the Yunnan Chenghai region recorded bylake sediments since 1800 [D], master Thesis, Yunnan Normal University, Kunming, 39-43, 2018.

MARGO Project Members: Constraints on the magnitude and patterns of ocean cooling at the Last Glacial Maximum, Nat. Geosci. 2, 127-132, https://doi.org/10.1038/ngeo411, 2009.

Marsicek, J., Shuman, B. N., Bartlein, P. J., Shafer, S. L., and Brewer, S.: Reconciling divergent trends and millennial variations in Holocene temperatures, Nature, 554, 92-96, https://doi.org/10.1038/nature25464, 2018.

Meegan Kumar, D., Woltering, M., Hopmans, E. C., Sinninghe Damsté, J. S., Schouten, S., and Werne, J. P.: The vertical distribution of Thaumarchaeota in the water column of Lake Malawi inferred from core and intact polar tetraether lipids, Org. Geochem., 132, 37-49, https://doi.org/10.1016/j.orggeochem.2019.03.004, 2019.

Ni, Z., Jones, R., Zhang, E., Chang, J., Shulmeister, J., Sun, W., Wang, Y., and Ning, D.: Contrasting effects of winter and summer climate on Holocene montane vegetation belts evolution in southeastern Qinghai-Tibetan Plateau, China, Palaeogeogr. Palaeocl., 533, 109232, https://doi.org/10.1016/j.palaeo.2019.06.005, 2019.

Ning, D., Zhang, E., Shulmeister, J., Chang, J., Sun, W., and Ni, Z.: Holocene mean annual air temperature (MAAT) reconstruction based on branched glycerol dialkyl glycerol tetraethers from Lake Ximenglongtan, southwestern China, Org. Geochem., 133, 65-76, https://doi.org/10.1016/j.orggeochem.2019.05.003, 2019.

Pearson, E. J., Juggins, S., Talbot, H. M., Weckstrom, J., Rosen, P., Ryves, D. B., Roberts, S. J., and Schmidt, R.: A lacustrine GDGT-temperature calibration from the Scandinavian Arctic to Antarctic: Renewed potential for the application of GDGTpaleothermometry in lakes, Geochim. Cosmochim. Ac., 75, 6225-6238, https://doi.org/10.1016/j.gca.2011.07.042, 2011.

Pitcher, A., Hopmans, E. C., Mosier, A. C., Park, S.-J., Rhee, S.K., Francis, C. A., Schouten, S., and Sinninghe Damsté, J. S.: Core and Intact Polar Glycerol Dibiphytanyl Glycerol Tetraether Lipids of Ammonia-Oxidizing Archaea Enriched from Marine and Estuarine Sediments, Appl. Environ. Microb., 77, 3468, https://doi.org/10.1128/AEM.02758-10, 2011.

Powers, L., Werne, J. P., Vanderwoude, A. J., Sinninghe Damsté, J. S., Hopmans, E. C., and Schouten, S.: Applicability and calibration of the $\mathrm{TEX}_{86}$ paleothermometer in lakes, Org. Geochem., 41, 404-413, https://doi.org/10.1016/j.orggeochem.2009.11.009, 2010. 
Powers, L. A., Werne, J. P., Johnson, T. C., Hopmans, E. C., Damsté, J. S. S., and Schouten, S.: Crenarchaeotal membrane lipids in lake sediments: A new paleotemperature proxy for continental paleoclimate reconstruction?, Geology, 32, 613-616, https://doi.org/10.1130/G20434.1, 2004.

Rashid, H., Flower, B. P., Poore, R. Z., and Quinn, T. M.: $A \sim 25 \mathrm{ka}$ Indian Ocean monsoon variability record from the Andaman Sea, Quaternary Sci. Rev., 26, 2586-2597, https://doi.org/10.1016/j.quascirev.2007.07.002, 2007.

R Development Core Team: A language and environment for statistical computing, R Foundation for Statistical Computing, Vienna, Austria, 2013.

Reimer, P. J., Bard, E., Bayliss, A., Beck, J. W., Blackwell, P. G., Ramsey, C. B., Buck, C. E., Cheng, H., Edwards, R. L., and Friedrich, M.: IntCal13 and Marine13 radiocarbon age calibration curves 0-50 000 years cal BP, Radiocarbon, 55, 1869-1887, https://doi.org/10.2458/azu_js_rc.55.16947, 2013.

Russell, J. M., Hopmans, E. C., Loomis, S. E., Liang, J., and Sinninghe Damsté, J. S.: Distributions of 5- and 6-methyl branched glycerol dialkyl glycerol tetraethers (brGDGTs) in East African lake sediment: Effects of temperature, $\mathrm{pH}$, and new lacustrine paleotemperature calibrations, Org. Geochem., 117, 56-69, https://doi.org/10.1016/j.orggeochem.2017.12.003, 2018.

Saraswat, R., Lea, D. W., Nigam, R., Mackensen, A., and Naik, D. K.: Deglaciation in the tropical Indian Ocean driven by interplay between the regional monsoon and global teleconnections, Earth. Planet. Sc. Lett., 375, 166-175, https://doi.org/10.1016/j.epsl.2013.05.022, 2013.

Schouten, S., Hopmans, E. C., Schefuß, E., and Sinninghe Damsté, J. S.: Distributional variations in marine crenarchaeotal membrane lipids: a new tool for reconstructing ancient sea water temperatures?, Earth. Planet. Sc. Lett., 204, 265-274, https://doi.org/10.1016/S0012-821X(02)00979-2, 2002.

Schouten, S., Rijpstra, W. I. C., Durisch-Kaiser, E., Schubert, C. J., and Sinninghe Damsté, J. S.: Distribution of glycerol dialkyl glycerol tetraether lipids in the water column of Lake Tanganyika, Org. Geochem., 53, 34-37, https://doi.org/10.1016/j.orggeochem.2012.01.009, 2012.

Schouten, S., Hopmans, E. C., and Sinninghe Damsté, J. S.: The organic geochemistry of glycerol dialkyl glycerol tetraether lipids: A review, Org. Geochem., 54, 19-61, https://doi.org/10.1016/j.orggeochem.2012.09.006, 2013.

Shen, C., Liu, K.-B., Tang, L., and Overpeck, J. T.: Quantitative relationships between modern pollen rain and climate in the Tibetan Plateau, Rev. Palaeobot. Palyno., 140, 61-77, https://doi.org/10.1016/j.revpalbo.2006.03.001, 2006.

Shuman, B., Bartlein, P. J., and Webb, T.: The magnitudes of millennial- and orbital-scale climatic change in eastern North America during the Late Quaternary, Quaternary Sci. Rev., 24, 2194-2206, https://doi.org/10.1016/j.quascirev.2005.03.018, 2005.

Sinha, A., Stott, L., Berkelhammer, M., Cheng, H., Edwards, R. L., Buckley, B., Aldenderfer, M., and Mudelsee, M.: A global context for megadroughts in monsoon Asia during the past millennium, Quaternary Sci. Rev., 30, 47-62, https://doi.org/10.1016/j.quascirev.2010.10.005, 2011.

Sinha, A., Kathayat, G., Cheng, H., Breitenbach, S. F. M., Berkelhammer, M., Mudelsee, M., Biswas, J., and Edwards, R. L.: Trends and oscillations in the Indian summer monsoon rain- fall over the last two millennia, Nat. Commun., 6, 6309, https://doi.org/10.1038/ncomms7309, 2015.

Sinninghe Damsté, J. S., Ossebaar, J., Abbas, B., Schouten, S., and Verschuren, D.: Fluxes and distribution of tetraether lipids in an equatorial African lake: Constraints on the application of the $\mathrm{TEX}_{86}$ palaeothermometer and BIT index in lacustrine settings, Geochim. Cosmochim. Ac., 73, 4232-4249, https://doi.org/10.1016/j.gca.2009.04.022, 2009.

Sinninghe Damsté, J. S., Ossebaar, J., Schouten, S., and Verschuren, D.: Distribution of tetraether lipids in the 25ka sedimentary record of Lake Challa: extracting reliable TEX $_{86}$ and MBT/CBT palaeotemperatures from an equatorial African lake, Quaternary Sci. Rev., 50, 43-54, https://doi.org/10.1016/j.quascirev.2012.07.001, 2012a.

Sinninghe Damsté, J. S., Rijpstra, W. I. C., Hopmans, E. C., Jung, M.-Y., Kim, J.-G., Rhee, S.-K., Stieglmeier, M., and Schleper, C.: Intact Polar and Core Glycerol Dibiphytanyl Glycerol Tetraether Lipids of Group I.1a and I.1b Thaumarchaeota in Soil, Appl. Environ Microb., 78, 6866-6874, https://doi.org/10.1128/AEM.01681-12, 2012b.

Sun, W., Zhang, E., Shulmeister, J., Bird, M. I., Chang, J., and Shen, $\mathrm{J}$.: Abrupt changes in Indian summer monsoon strength during the last deglaciation and early Holocene based on stable isotope evidence from Lake Chenghai, southwest China, Quaternary Sci. Rev., 218, 1-9, https://doi.org/10.1016/j.quascirev.2019.06.006, 2019.

Tian, L., Wang, M., Zhang, X., Yang, X., Zong, Y., Jia, G., Zheng, Z., and Man, M.: Synchronous change of temperature and moisture over the past $50 \mathrm{ka}$ in subtropical southwest China as indicated by biomarker records in a crater lake, Quaternary Sci. Rev., 212, 121-134, https://doi.org/10.1016/j.quascirev.2019.04.003, 2019.

Tierney, J. E., Russell, J. M., Huang, Y., Damsté, J. S. S., Hopmans, E. C., and Cohen, A. S.: Northern Hemisphere controls on tropical southeast African climate during the past 60000 years, Science, 322, 252-255, https://doi.org/10.1126/science.1160485, 2008.

Tierney, J. E., Russell, J. M., Eggermont, H., Hopmans, E. C., Verschuren, D., and Damste, J. S. S.: Environmental controls on branched tetraether lipid distributions in tropical East African lake sediments, Geochim. Cosmochim. Ac., 74, 4902-4918, https://doi.org/10.1016/j.gca.2010.06.002, 2010.

Wan, G. J., Chen, J. A., Wu, F. C., Xu, S. Q., Bai, Z. G., Wan, E. Y., Wang, C. S., Huang, R. G., Yeager, K. M., and Santschi, P. H.: Coupling between ${ }^{210} \mathrm{~Pb}_{\mathrm{ex}}$ and organic matter in sediments of a nutrient-enriched lake: An example from Lake Chenghai, China. Chem Geol., 224, 223-236, https://doi.org/10.1016/j.chemgeo.2005.07.025, 2005.

Wang, H., Dong, H., Zhang, C. L., Jiang, H., Zhao, M., Liu, Z., Lai, Z., and Liu, W.: Water depth affecting thaumarchaeol production in Lake Qinghai, northeastern Qinghai-Tibetan plateau: Implications for paleo lake levels and paleoclimate, Chem. Geol., 368, 76-84, https://doi.org/10.1016/j.chemgeo.2014.01.009, 2014.

Wang, H., Dong, H., Zhang, C. L., Jiang, H., Liu, Z., Zhao, M., and Liu, W.: Deglacial and Holocene archaeal lipid-inferred paleohydrology and paleotemperature history of Lake Qinghai, northeastern Qinghai-Tibetan Plateau, Quaternary Res., 83, 116-126, https://doi.org/10.1016/j.yqres.2014.10.003, 2015. 
Wang, H., Leng, Q., Liu, W., and Yang, H.: A rapid lake-shallowing event terminated preservation of the Miocene Clarkia Fossil Konservat-Lagerstätte (Idaho, USA), Geology, 45, 239-242, https://doi.org/10.1130/G38434.1, 2017.

Wang, H., He, Y., Liu, W., Zhou, A., Kolpakova, M., Krivonogov, S., and Liu, Z.: Lake Water Depth Controlling Archaeal Tetraether Distributions in Midlatitude Asia: Implications for Paleo Lake-Level Reconstruction, Geophys. Res. Lett., 46, 52745283, https://doi.org/10.1029/2019GL082157, 2019.

Wang, M., Zheng, Z., Man, M., Hu, J., and Gao, Q.: Branched GDGT-based paleotemperature reconstruction of the last 30,000 years in humid monsoon region of Southeast China, Chem. Geol., 463, 94-102, https://doi.org/10.1016/j.chemgeo.2017.05.014, 2017.

Wang, M., Tian, Q., Li, X., Liang, J., He, Y., and Hou, J.: $\mathrm{TEX}_{86}$ as a potential proxy of lake water $\mathrm{pH}$ in the Tibetan Plateau, Palaeogeogr. Palaeocl., 538, 109381, https://doi.org/10.1016/j.palaeo.2019.109381, 2020.

Wang, Q., Yang, X., Anderson, N. J., Zhang, E., and Li, Y.: Diatom response to climate forcing of a deep, alpine lake (Lugu $\mathrm{Hu}$, Yunnan, SW China) during the Last Glacial Maximum and its implications for understanding regional monsoon variability, Quaternary Sci. Rev., 86, 1-12, https://doi.org/10.1016/j.quascirev.2013.12.024, 2014 b.

Wang, S. and Dou, H.: Lakes in China, Science Press, Beijing, China, 1998 (in Chinese).

Weijers, J. W. H., Schouten, S., Spaargaren, O. C., and Damste, J. S. S.: Occurrence and distribution of tetraether membrane lipids in soils: Implications for the use of the $\mathrm{TEX}_{86}$ proxy and the BIT index, Org. Geochem., 37, 1680-1693, https://doi.org/10.1016/j.orggeochem.2006.07.018, 2006.

Wu, D., Zhou, A., Chen, X., Yu, J., Zhang, J., and Sun, H.: Hydrological and ecosystem response to abrupt changes in the Indian monsoon during the last glacial, as recorded by sediments from Xingyun Lake, Yunnan, China, Palaeogeogr. Palaeocl., 421, 1523, https://doi.org/10.1016/j.palaeo.2015.01.005, 2015.

Wu, D., Chen, X., Lv, F., Brenner, M., Curtis, J., Zhou, A., Chen, J., Abbott, M., Yu, J., and Chen, F.: Decoupled early Holocene summer temperature and monsoon precipitation in southwest China, Quaternary Sci. Rev., 193, 54-67, https://doi.org/10.1016/j.quascirev.2018.05.038, 2018.

Wu, J., Gagan, M. K., Jiang, X., Xia, W., and Wang, S.: Sedimentary geochemical evidence for recent eutrophication of Lake Chenghai, Yunnan, China, J. Paleoclim., 32, 85-94, 2004.
Yang, H., Lu, X. X., Ding, W. H., Lei, Y. Y., Dang, X. Y., and Xie, S. C.: The 6-methyl branched tetraethers significantly affect the performance of the methylation index (MBT') in soils from an altitudinal transect at Mount Shennongjia, Org. Geochem., 82, 42-53, https://doi.org/10.1016/j.orggeochem.2015.02.003, 2015.

Yang, H., Xiao, W., Słowakiewicz, M., Ding, W., Ayari, A., Dang, X., and Pei, H.: Depth-dependent variation of archaeal ether lipids along soil and peat profiles from southern China: Implications for the use of isoprenoidal GDGTs as environmental tracers, Org. Geochem., 128, 42-56, https://doi.org/10.1016/j.orggeochem.2018.12.009, 2019.

Yao, Y., Zhao, J., Bauersachs, T., and Huang, Y.: Effect of water depth on the $\mathrm{TEX}_{86}$ proxy in volcanic lakes of northeastern China, Org. Geochem., 129, 88-98, https://doi.org/10.1016/j.orggeochem.2019.01.014, 2019.

Zhang, E., Wang, Y., Sun, W., and Shen, J.: Holocene Asian monsoon evolution revealed by a pollen record from an alpine lake on the southeastern margin of the Qinghai-Tibetan Plateau, China, Clim. Past, 12, 415-427, https://doi.org/10.5194/cp-12415-2016, 2016.

Zhang, E., Chang, J., Cao, Y., Sun, W., Shulmeister, J., Tang, H., Langdon, P. G., Yang, X., and Shen, J.: Holocene highresolution quantitative summer temperature reconstruction based on subfossil chironomids from the southeast margin of the Qinghai-Tibetan Plateau, Quaternary Sci. Rev., 165, 1-12, https://doi.org/10.1016/j.quascirev.2017.04.008, 2017a.

Zhang, E., Zhao, C., Xue, B., Liu, Z., Yu, Z., Chen, R., and Shen, J.: Millennial-scale hydroclimate variations in southwest China linked to tropical Indian Ocean since the Last Glacial Maximum, Geology, 45, 435-438, https://doi.org/10.1130/G38309.1, 2017b.

Zhang, E., Sun, W., Chang, J., Ning, D., and Shulmeister, J.: Variations of the Indian summer monsoon over the last 30000 years inferred from a pyrogenic carbon record from south-west China, J. Quaternary Sci., 33, 131-138, https://doi.org/10.1002/jqs.3008, 2018.

Zhang, E., Chang, J., Shulmeister, J., Langdon, P., Sun, W., Cao, Y., Yang, X., and Shen, J.: Summer temperature fluctuations in Southwestern China during the end of the LGM and the last deglaciation, Earth. Planet. Sc. Lett., 509, 78-87, https://doi.org/10.1016/j.epsl.2018.12.024, 2019.

Zheng, Y., Pancost, R. D., Naafs, B. D. A., Li, Q., Liu, Z., and Yang, H.: Transition from a warm and dry to a cold and wet climate in NE China across the Holocene, Earth. Planet. Sc. Lett., 493, 3646, https://doi.org/10.1016/j.eps1.2018.04.019, 2018. 